\title{
Microalgal Growth in Paper Industry Effluent: Coupling Biomass Production with Nutrients Removal
}

\author{
Bruna Porto ${ }^{1,2}$, Ana L. Gonçalves ${ }^{3, *}{ }^{\mathbb{D}}$, Ana F. Esteves ${ }^{3}$, Selene M. A. Guelli Ulson de Souza ${ }^{1}(\mathbb{D}$, \\ Antônio A. Ulson de Souza ${ }^{1}\left[\right.$, Vítor J. P. Vilar ${ }^{2}$ and José C. M. Pires ${ }^{3} \mathbb{C}$ \\ 1 Laboratory of Numerical Simulation of Chemical Systems and Mass Transfer (LABSIN-LABMASSA), \\ Federal University of Santa Catarina, Chemical and Food Engineering Department, PO Box 476, \\ 88040-900 Florianópolis/SC, Brazil; b.porto@hotmail.com (B.P.); selene.souza@ufsc.br (S.M.A.G.U.d.S.); \\ antonio.augusto.ulson.souza@gmail.com (A.A.U.d.S.) \\ 2 Laboratory of Separation and Reaction Engineering - Laboratory of Catalysis and Materials (LSRE-LCM), \\ Faculty of Engineering, University of Porto, Rua Dr Roberto Frias, 4200-465 Porto, Portugal; vilar@fe.up.pt \\ 3 LEPABE - Laboratory for Process Engineering, Environment, Biotechnology and Energy, Faculty of \\ Engineering, University of Porto, Rua Dr Roberto Frias, 4200-465 Porto, Portugal; \\ afcesteves@fe.up.pt (A.F.E.); jcpires@fe.up.pt (J.C.M.P.) \\ * Correspondence: algoncalves@fe.up.pt; Tel.: +351-22-041-3656
}

Received: 31 March 2020; Accepted: 24 April 2020; Published: 26 April 2020 updates

\begin{abstract}
Paper and pulp industries produce effluents with high phosphorus concentrations, which need to be treated before their discharge in watercourses. The use of microalgae for this purpose has attracted the attention of researchers because: (i) microalgae can assimilate phosphorus (one of the main nutrients for their growth); and (ii) growing on effluents can significantly reduce the costs and environmental impact of microalgal biomass production. This study evaluated the growth and ability of Chlorella vulgaris to remove the phosphorus from a secondary-treated effluent of a Portuguese paper company. Batch experiments were performed for 11 days using different dilutions of the effluent to evaluate its inhibitory effect on microalgae. Results showed that the non-diluted effluent inhibited microalgal growth, indicating that this bioremediation process is possible after a previous dilution of the effluent. Regarding phosphorus removal, promising results were achieved, especially in the experiments conducted with the most diluted effluent: removal efficiencies obtained in these conditions were $(54 \pm 1) \%$. Another interesting finding of this study was microalgal growth in flakes' form (mainly due to the compounds present in the effluent and to the $\mathrm{pH}$ values achieved), which can be an important economic advantage for biomass recovery after the remediation step.
\end{abstract}

Keywords: biomass production; Chlorella vulgaris; microalgae; nutrients removal; paper industry effluent; effluent treatment

\section{Introduction}

Paper and pulp industries require large amounts of water during their manufacturing stages. For example, the production of $1 \mathrm{~kg}$ of paper requires 10 to $50 \mathrm{~L}$ of water [1]. At the same time, large amounts of effluents (about $2000 \mathrm{~m}^{3} \mathrm{~d}^{-1}$ ) are generated, presenting as main features [1,2]: (i) high chemical oxygen demand (COD, 1000-13,000 $\mathrm{mg}_{\mathrm{O} 2} \mathrm{~L}^{-1}$ ); (ii) high total suspended solids contents; (iii) non-biodegradable organic materials; (iv) adsorbable organic halogens (AOX): (v) color; (vi) phenolic compounds; (vii) high total phosphorus contents; and (viii) limiting nitrogen concentrations. Due to the large volumes involved and respective compositions, discharge of these effluents without any treatment can cause several environmental problems [1,3]: (i) colored effluents can affect aesthetics, 
water transparency and gas solubility in water bodies; (ii) increase in the concentration of toxic compounds, which can affect aquatic flora and fauna; and (iii) eutrophication with consequent decrease of dissolved oxygen concentration and $\mathrm{pH}$ oscillations, which can negatively impact aquatic ecosystems. Therefore, treatment of these effluents is necessary before their discharge.

Among the contaminants present in these effluents, phosphorus is of particular concern, as it subsists in the effluents after the secondary treatment step and is one of the main contributors to the eutrophication phenomenon [4]. Currently applied methods to reduce phosphorus concentration in these effluents include physicochemical methods, such as precipitation using aluminum and iron salts. However, these techniques tend to be costly and to produce large amounts of sludge contaminated with the referred chemical compounds, requiring further treatment $[5,6]$. Therefore, microalgal cultures have appeared as a feasible alternative to conventional physicochemical methods. These microorganisms have shown their ability to effectively remove color, nutrients, such as nitrogen and phosphorus, trace metals and other compounds from the culture medium $[7,8]$.

Microalgae are fast-growing photosynthetic microorganisms that have gained much attention in recent decades, due to their high potential in a wide variety of applications. During photosynthesis, microalgae uptake $\mathrm{CO}_{2}$ from the atmosphere or flue gas emissions, contributing to the reduction of the atmospheric concentration of this greenhouse gas [9]. These microorganisms also require inorganic sources of nitrogen and phosphorus as macronutrients, enabling the use of microalgal cultures as a tertiary treatment stage (when significant concentrations of these nutrients persist after previous treatment processes) [10]. Finally, microalgal biomass presents a very rich composition in polysaccharides, lipids, proteins, vitamins, and other valuable compounds, which make microalgae a valuable resource for several applications [11,12], such as the production of natural colorants or dyes, bioenergy, and biofertilizers. Also, effluent treatment with microalgae has the following advantages [10]: (i) reduction of nitrogen and phosphorus concentrations to levels below the legislated limits for effluent discharge (EU Directives 1991/271/EEC and 1998/15/EC); (ii) recovery/recycle of these nutrients, which production presents negative environmental impacts; (iii) increase of the oxygen concentration in the treated effluent; (iv) production of biomass that can be integrated into the value chain of the company; and (v) reduction of net carbon dioxide emissions.

Despite the need to search for eco-friendly and cost-effective remediation strategies, only a few studies have reported the treatment of pulp and paper industry effluents using microalgae [1]. Tarlan et al. [7] evaluated the removal of color, AOX, and COD from an effluent resulting from a wood-based pulp and paper Turkish company using a mixed microalgal culture (composed by Chlorella and diatoms). Initial composition of this effluent in terms of color, AOX, and COD was: $4018 \mathrm{Pt}-\mathrm{Co}$, $46.3 \mathrm{mg} \mathrm{L}^{-1}$ and $1248 \mathrm{mg} \mathrm{L}^{-1}$, respectively. Operating in batch mode and using three different dilutions of this effluent, resulting from the process of pulp production using red pine, the authors reported removal efficiencies of $84 \%, 80 \%$ and $58 \%$ for color, AOX, and COD, respectively. Gentili [13] aimed to evaluate the growth of microalgae on mixtures of municipal, dairy, and pulp and paper effluents to achieve the dual goal of nutrients removal and lipids production. The use of mixtures of pulp and paper industry effluents with municipal and dairy ones was to evaluate if these mixtures could (i) promote microalgal growth without previous dilution with freshwater; and (ii) provide the required nutrients for biomass production without the need for nutrients supplementation. Characterization of these mixtures revealed an ammonium-nitrogen $\left(\mathrm{NH}_{4}-\mathrm{N}\right)$ concentration ranging from $14.75 \mathrm{mg}_{\mathrm{N}} \mathrm{L}^{-1}$ to $22.35 \mathrm{mg}_{\mathrm{N}} \mathrm{L}^{-1}$, a nitrate-nitrogen $\left(\mathrm{NO}_{3}-\mathrm{N}\right)$ concentration between $1.6 \mathrm{mg}_{\mathrm{N}} \mathrm{L}^{-1}$ and $10.1 \mathrm{mg}_{\mathrm{N}} \mathrm{L}^{-1}$ and a phosphate-phosphorus $\left(\mathrm{PO}_{4}-\mathrm{P}\right)$ concentration ranging between $1.06 \mathrm{mg}_{\mathrm{P}} \mathrm{L}^{-1}$ and $1.25 \mathrm{mg}_{\mathrm{P}} \mathrm{L}^{-1}$. With this study, carried out in laboratory tubes, in batch mode, the authors demonstrated that the microalgae Scenedesmus sp., Scenedesmus dimorphus and Selenastrum minutum were able to achieve nitrogen and phosphorus removal efficiencies of $96 \%-99 \%$ and $91 \%-99 \%$, respectively. Finally, in the study performed by Usha, et al. [1], a mixed microalgal culture (composed by two Scenedesmus species) was grown in different dilutions $(0 \%-95 \%)$ of a pulp and paper mill effluent, resulting from an Indian company, with the following composition: (i) $9.932 \mathrm{mg}_{\mathrm{N}} \mathrm{L}^{-1}$ of $\mathrm{NO}_{3}-\mathrm{N}$; (ii) $30.25 \mathrm{mg}_{\mathrm{P}} \mathrm{L}^{-1}$ of 
$\mathrm{PO}_{4}-\mathrm{P}$; (iii) $3000.15 \mathrm{mg} \mathrm{L}{ }^{-1}$ of COD; and (iv) $2944 \mathrm{mg} \mathrm{L}^{-1}$ of biochemical oxygen demand (BOD). The experiments, aimed at evaluating both biomass production and nutrients removal efficiencies, were performed in batch mode, for 28 days, using open ponds as cultivation system (outdoor conditions). Regarding nutrients uptake, the most promising results were obtained for the $40 \%$ dilution: (i) $65 \%$ for $\mathrm{NO}_{3}-\mathrm{N}$ removal; (ii) $81.3 \%$ for $\mathrm{PO}_{4}-\mathrm{P}$; and (iii) $75 \%$ for COD; and (iv) $82 \%$ for $\mathrm{BOD}$.

The main goal of the present study was to evaluate biomass production and phosphorus removal from a secondary-treated effluent of a Portuguese paper company using the microalga Chlorella vulgaris. Different dilutions were performed to evaluate possible inhibitory effects of the effluent on microalgal growth and phosphorus uptake ability.

\section{Materials and Methods}

\subsection{Microalgae Strain and Maintenance Medium}

The microalga C. vulgaris (CCAP 211/11B) was obtained from the Culture Collection of Algae and Protozoa, United Kingdom. The strain was maintained on modified Organization for Economic Co-operation and Development (OECD) culture medium [14], with the following composition (mg L-1): $119 \mathrm{KNO}_{3} ; 12 \mathrm{MgCl}_{2} \cdot 2 \mathrm{H}_{2} \mathrm{O} ; 18 \mathrm{CaCl}_{2} \cdot 2 \mathrm{H}_{2} \mathrm{O} ; 15 \mathrm{MgSO}_{4} \cdot 7 \mathrm{H}_{2} \mathrm{O} ; 20 \mathrm{KH}_{2} \mathrm{PO}_{4}$; $0.08 \mathrm{FeCl}_{3} \cdot 6 \mathrm{H}_{2} \mathrm{O} ; 0.1 \mathrm{Na}_{2} \mathrm{EDTA} \cdot 2 \mathrm{H}_{2} \mathrm{O} ; 0.185 \mathrm{H}_{3} \mathrm{BO}_{3} ; 0.415 \mathrm{MnCl}_{2} \cdot 4 \mathrm{H}_{2} \mathrm{O} ; 0.003 \mathrm{ZnCl}_{2} ; 0.0015 \mathrm{CoCl}_{2} \cdot 6 \mathrm{H}_{2} \mathrm{O}$; $0.00001 \mathrm{CuCl}_{2} \cdot 2 \mathrm{H}_{2} \mathrm{O} ; 0.007 \mathrm{Na}_{2} \mathrm{MoO}_{4} \cdot 2 \mathrm{H}_{2} \mathrm{O}$ and $100 \mathrm{Na}_{2} \mathrm{CO}_{3}$.

\subsection{Paper Industry Effluent and Culture Conditions}

Effluent from a Portuguese paper company, collected after the secondary treatment step, was characterized (Table 1) and employed as a culture medium for microalgal growth. The methodology adopted for effluent characterization was the following: (i) COD and turbidity were determined according to the Standard Methods for the Examination of Water and Wastewater [15] (through the 5220-D and 2130-B tests, respectively); (ii) total dissolved carbon (TDC), dissolved organic carbon (DOC) and inorganic carbon (DIC) were determined using an organic carbon analyzer (TOC- $\mathrm{V}_{\mathrm{CSN}}$, Shimadzu); and (iii) chlorides, sulfates, nitrates, nitrites and phosphates were determined through ion chromatography (ICS-2100, Dionex). Due to the low concentration of nitrogen in the effluent, when compared with typical nutritional requirements of microalgae, the effluent was supplemented with $\mathrm{NaNO}_{3}$ to achieve N:P molar ratios ranging between 6:1 and 9:1. Ratios between 5:1 and 30:1 have been considered adequate for several microalgal species $[16,17]$.

Table 1. Physicochemical characterization of the paper industry effluent used in this study.

\begin{tabular}{ccc}
\hline Parameters & Values & Unit \\
\hline Turbidity & 1.55 & $\mathrm{NTU}^{\mathrm{a}}$ \\
$\mathrm{pH}$ & 7.02 & - \\
Dissolved organic carbon (DOC) & 296 & $\mathrm{mg} \mathrm{L}^{-1}$ \\
Total dissolved carbon (TDC) & 369 & $\mathrm{mg} \mathrm{L}^{-1}$ \\
Dissolved inorganic carbon (DIC) & 72.5 & $\mathrm{mg} \mathrm{L}^{-1}$ \\
Soluble chemical oxygen demand (COD $)$ & 323 & $\mathrm{mg} \mathrm{L}^{-1}$ \\
Chlorides $\left(\mathrm{Cl}^{-}\right)$ & 671 & $\mathrm{mg} \mathrm{L}^{-1}$ \\
Sulfates $\left(\mathrm{SO}_{4}{ }^{2-}\right)$ & 808 & $\mathrm{mg} \mathrm{L}^{-1}$ \\
Phosphate-phosphorus $\left(\mathrm{PO}_{4}-\mathrm{P}\right)$ & 12.3 & $\mathrm{mg} \mathrm{L}^{-1}$ \\
Nitrate-nitrogen $\left(\mathrm{NO}_{3}-\mathrm{N}\right)$ & 8.73 & $\mathrm{mg} \mathrm{L}^{-1}$ \\
Nitrite-nitrogen $\left(\mathrm{NO}_{2}-\mathrm{N}\right)$ & 3.42 &
\end{tabular}

${ }^{a}$ Nephelometric turbidity unit.

Batch experiments were performed in $1-\mathrm{L}$ borosilicate glass flasks (VWR, Portugal) with a working volume of $950 \mathrm{~mL}$ for 11 days. The raw effluent (assay 1) and four different dilutions 
with freshwater (assays 2-5) were used as the culture medium for microalgal growth, with nitrogen concentrations (corresponding to the sum between nitrate- and nitrite-nitrogen) ranging between $12.7 \mathrm{mg} \mathrm{L}_{\mathrm{N}} \mathrm{L}^{-1}$ and $34.2 \mathrm{mg}_{\mathrm{N}} \mathrm{L}^{-1}$ and phosphorus concentrations (phosphate-phosphorus) ranging between $4.01 \mathrm{mg} \mathrm{L}^{-1}$ and $12.3 \mathrm{mg}_{\mathrm{P}} \mathrm{L}^{-1}$. The medium was inoculated with $250 \mathrm{~mL}$ of $C$. vulgaris inoculum to obtain an initial biomass concentration of $\sim 68 \mathrm{mg}_{\mathrm{dw}} \mathrm{L}^{-1}$. The cultures were continuously exposed to: (i) photosynthetically active radiation between $30-40 \mu \mathrm{mol} \mathrm{m}^{-2} \mathrm{~s}^{-1}$, using a 34-W white led panel; and (ii) atmospheric air filtered with $0.45-\mu$ m nylon membranes (Specanalitica, Portugal), injected at $\sim 90 \mathrm{~L} \mathrm{~h}^{-1}$, using Trixie AP 180 air pumps (Trixie, Tarp, Germany). The experimental setup is shown in Figure 1. Two independent experiments were performed for each assay.

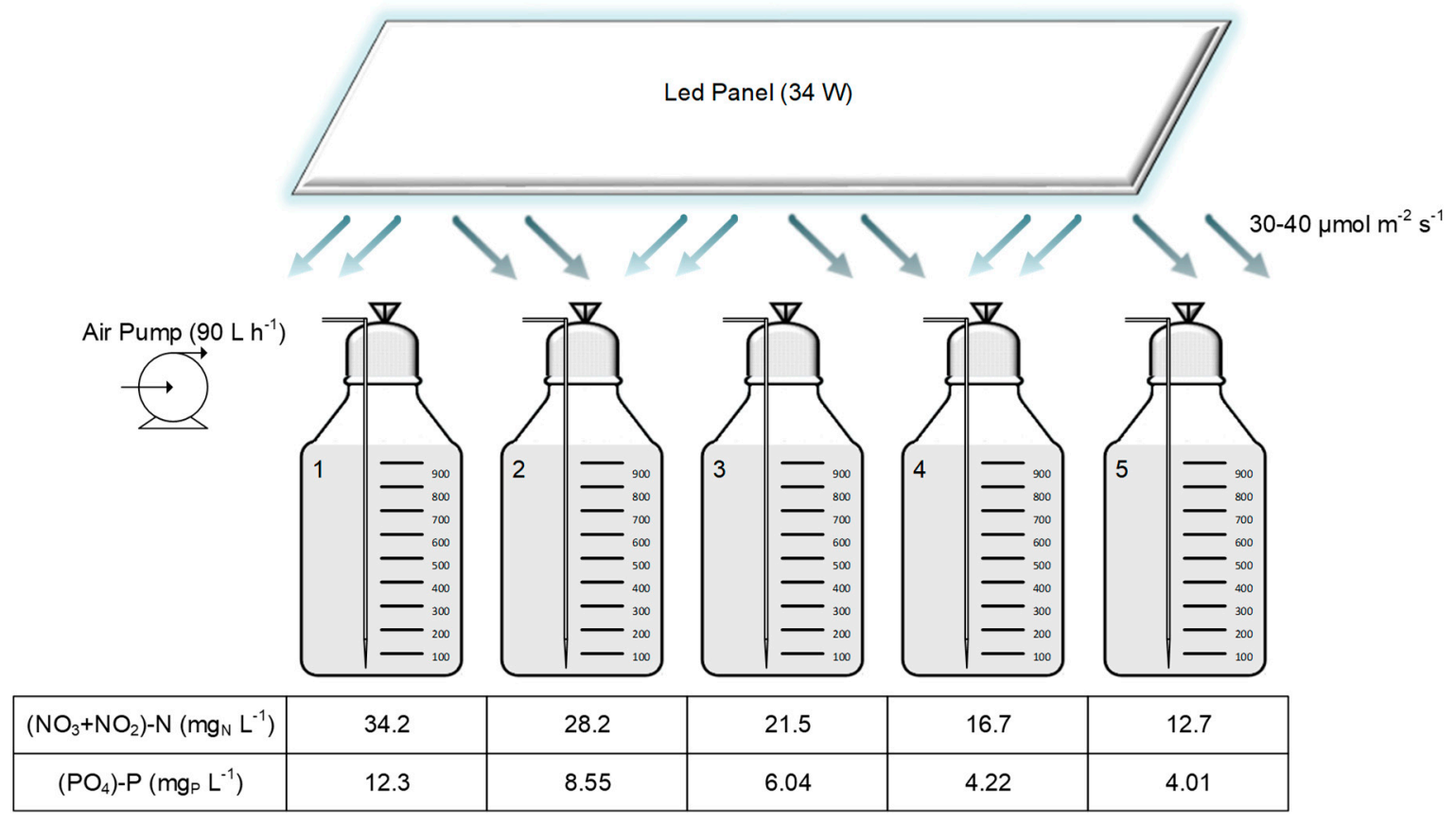

Figure 1. Schematic representation of the experimental setup.

\subsection{Microalgal Growth Monitoring and Kinetic Growth Parameters}

Operational parameters, such as $\mathrm{pH}$ and temperature, were daily monitored using a SympHony SB90M5 pH-meter (VWR, Portugal). Microalgal growth was also daily assessed through optical density measurements at $680 \mathrm{~nm}\left(\mathrm{OD}_{680}\right)$ using a UV-6300 PC spectrophotometer (VWR, United States). To eliminate the interference of the effluent color on $\mathrm{OD}_{680}$ measurements, the cells were separated from the culture medium by centrifugation (at $4000 \mathrm{rpm}$, for $10 \mathrm{~min}$ ), the supernatant was discarded, and the cells were resuspended in an equal volume of distilled water, as described by Hodaifa, et al. [18]. This procedure was repeated twice. The relationship between $\mathrm{OD}_{680}$ and biomass concentration $\left(X, \mathrm{mg}_{\mathrm{dw}}\right.$ $\mathrm{L}^{-1}$ ) for C. vulgaris was previously established by linear regression, according to Equation (1):

$$
\mathrm{X}=0.0024 \times \mathrm{OD}_{680}+0.0030 \mathrm{R}^{2}=0.9999,
$$

Biomass concentrations were used to determine the kinetic growth parameters: (i) specific growth rates $\left(\mu, \mathrm{d}^{-1}\right)$; and (ii) maximum and average biomass productivities $\left(P_{\max }\right.$ and $\left.P_{\text {aver }}, \mathrm{mg}_{\mathrm{dw}} \mathrm{L}^{-1} \mathrm{~d}^{-1}\right)$. The specific growth rates were determined from the first-order kinetic model, according to Equation (2):

$$
\frac{\mathrm{dX}}{\mathrm{dt}}=\mu X \leftrightarrow \mu=\frac{\ln \mathrm{X}_{1}-\ln \mathrm{X}_{0}}{\mathrm{t}_{1}-\mathrm{t}_{0}}
$$


where $X_{1}$ and $X_{0}$ correspond, respectively, to biomass concentration $\left(\mathrm{mg}_{\mathrm{dw}} \mathrm{L}^{-1}\right)$ in the end $\left(t_{1}, \mathrm{~d}\right)$ and beginning $\left(t_{0}, \mathrm{~d}\right)$ of the exponential growth phase. Biomass productivities $\left(P, \mathrm{mg}_{\mathrm{dw}} \mathrm{L}^{-1} \mathrm{~d}^{-1}\right)$ were calculated for each pair of consecutive points, through Equation (3):

$$
P=\frac{X_{z+1}-X_{z}}{t_{z+1}-t_{z}}
$$

where $X_{z}$ represents the biomass concentration $\left(\mathrm{mg}_{\mathrm{dw}} \mathrm{L}^{-1}\right)$ at time $t_{z}(\mathrm{~d})$ and $X_{z+1}$ corresponds to the biomass concentration $\left(\mathrm{mg}_{\mathrm{dw}} \mathrm{L}^{-1}\right)$ at time $t_{z+1}(\mathrm{~d})$. The maximum productivity was determined from the maximum value obtained from Equation (3). On the other hand, average biomass productivities were determined according to Equation (4):

$$
P_{\text {aver }}=\frac{X_{f}-X_{i}}{t_{f}-t_{i}}
$$

where $X_{f}$ and $X_{i}$ correspond, respectively, to biomass concentration $\left(\mathrm{mg}_{\mathrm{dw}} \mathrm{L}^{-1}\right)$ in the end $\left(t_{f}, \mathrm{~d}\right)$ and beginning $\left(t_{i}, \mathrm{~d}\right)$ of the cultivation period.

\subsection{Nutrients Removal}

Nutrients removal was evaluated in terms of nitrogen and $(\mathrm{N})$ phosphorus $(\mathrm{P})$ present in the culture medium/effluent. Nitrogen was assessed in the forms of nitrate and nitrite ions, whereas phosphorus was monitored through the presence of phosphate ions. From each assay, $5 \mathrm{~mL}$ of the microalgal suspension were periodically collected (days $0,1,2,4,7,9$, and 11). These samples were centrifuged at $4000 \mathrm{rpm}$, for $10 \mathrm{~min}$, and the supernatants were filtered through $0.45-\mu \mathrm{m}$ nylon membranes (Specanalitica, Portugal). Nitrate, nitrite and phosphate concentrations were determined in an ion chromatograph (ICS-2100, Dionex) equipped with an anion analytical column (4x $250 \mathrm{~mm}$, AS11-HC) and a self-regeneration suppressor (4 mm, AERS 500). The values obtained in the first and last day of culturing were used to calculate the following removal parameters: (i) removal efficiencies $(\% R, \%)$; (ii) average removal rates $\left(R R, \mathrm{mg} \mathrm{L}^{-1} \mathrm{~d}^{-1}\right)$; and (iii) mass removal $\left(R, \mathrm{mg} \mathrm{L}^{-1}\right)$, as shown in Equations (5), (6) and (7), respectively:

$$
\begin{gathered}
\% R=\frac{S_{f}-S_{i}}{S_{i}} \times 100, \\
R R=\frac{S_{f}-S_{i}}{t_{f}-t_{i}}, \\
R=S_{f}-S_{i},
\end{gathered}
$$

where $S_{f}$ and $S_{i}$ correspond to the nitrogen (nitrate + nitrite) or phosphorus (phosphate) concentration $\left(\mathrm{mg} \mathrm{L}^{-1}\right)$ in the end $\left(t_{f}, \mathrm{~d}\right)$ and beginning $\left(t_{i}, \mathrm{~d}\right)$ of the cultivation period, respectively.

\subsection{Statistical Analysis}

Each parameter shown in the present paper was expressed as the mean and standard deviation. The Tukey statistical test was used to investigate if the differences between the different effluent concentrations studied could be considered significant. These statistical tests were performed using Statistica 8.0 (StatSoft Inc., USA) and were carried out at a significance level ( $p$ ) of 0.05 .

\section{Results and Discussion}

\subsection{Microalgal Growth}

The C. vulgaris growth curves in raw and diluted paper industry effluent are shown in Figure 2. These results evidence the inexistence of an adaptation phase for all assays and an exponential growth 
phase that lasted approximately four days. In addition, no cell decay was observed during the 11-day batch culture, indicating that the experiments could be extended for a longer period. The increase of biomass concentration during the cultivation period, as well as the lack of an adaptation phase, shows that $C$. vulgaris was able to grow in this effluent. However, biomass concentrations achieved in non-diluted effluent (assay 1) were statistically lower $(p<0.05)$ than those achieved in more diluted effluents from assays $3-5$.

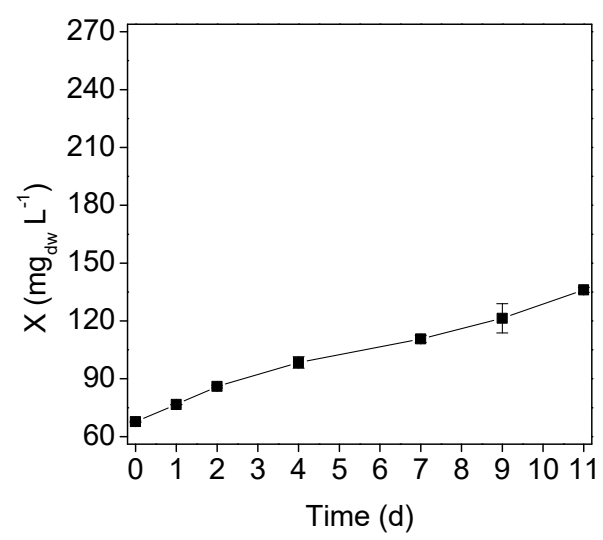

(A)

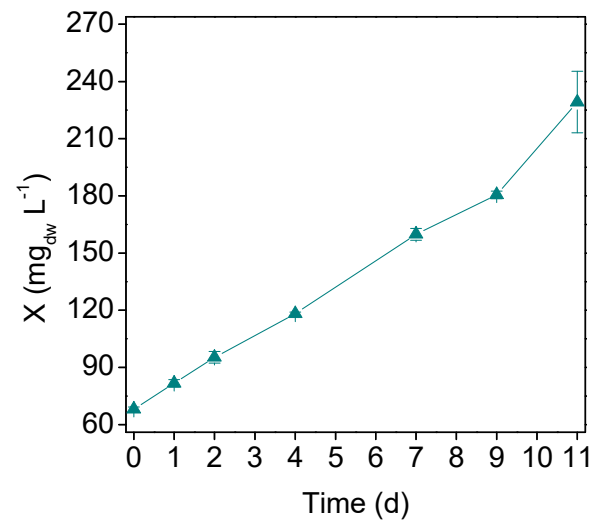

(C)

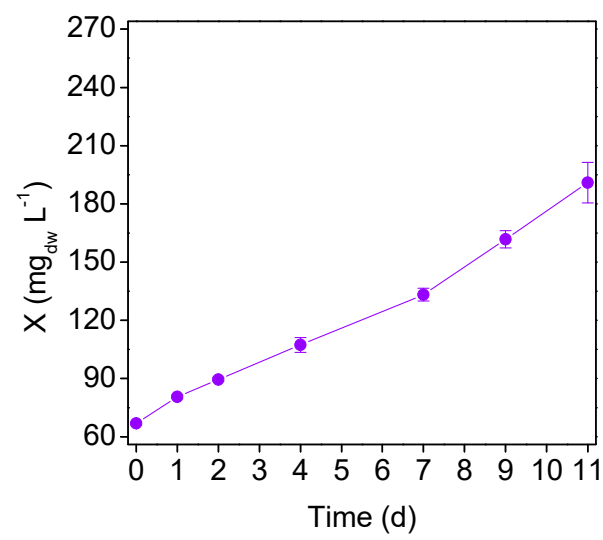

(B)

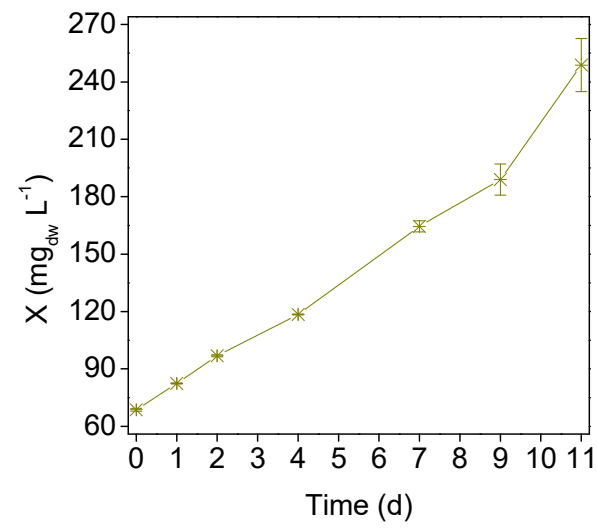

(D)

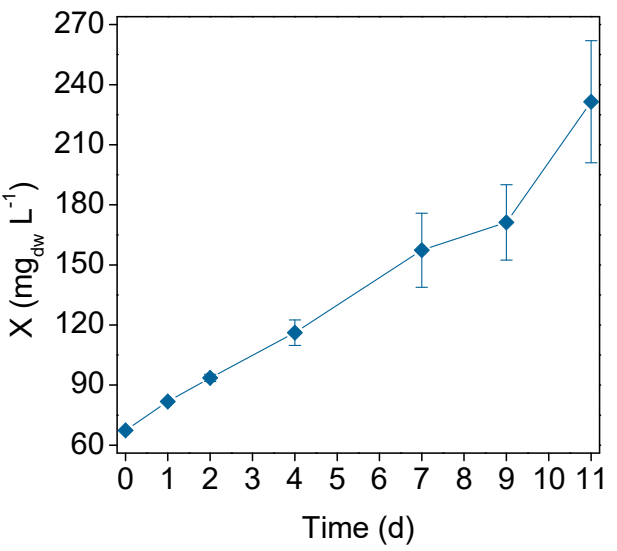

(E)

Figure 2. C. vulgaris cultures growth curves in raw and diluted secondary-treated paper industry

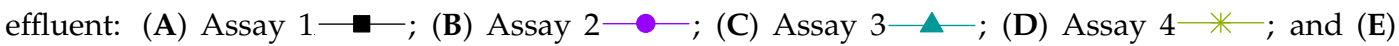
Assay $5-$ Error bars correspond to the standard deviation of the mean obtained from two independent experiments. 
To complement the analysis from growth curves, microalgal growth parameters, such as specific growth rate, maximum biomass concentration, and maximum and average biomass productivities, were determined and presented in Table 2. From these data, it is possible to see a general increase in growth parameters from assay 1 to assay 5, i.e., from the non-diluted effluent to the more diluted one. Regarding specific growth rates, values ranged from $(0.093 \pm 0.007) \mathrm{d}^{-1}$ to $(0.16 \pm 0.02) \mathrm{d}^{-1}$ in assays 1 and 5, respectively. The highest values of maximum biomass concentrations were also obtained in more diluted effluents from assays 4 and 5: $(249 \pm 14) \mathrm{mg}_{\mathrm{dw}} \mathrm{L}^{-1}$ and $(231 \pm 31) \mathrm{mg}_{\mathrm{dw}} \mathrm{L}^{-1}$, respectively. Similar behavior was observed for both maximum and average biomass productivities. Maximum biomass productivities/average biomass productivities obtained in assays 4 and 5 were $(30 \pm 3) /(16 \pm 1) \mathrm{mg}_{\mathrm{dw}} \mathrm{L}^{-1} \mathrm{~d}^{-1}$ and $(30 \pm 6) /(15 \pm 3) \mathrm{mg}_{\mathrm{dw}} \mathrm{L}^{-1} \mathrm{~d}^{-1}$, respectively. In opposition, maximum and average biomass productivities obtained in assay 1 were $(9.8 \pm 0.2) \mathrm{mg}_{\mathrm{dw}} \mathrm{L}^{-1} \mathrm{~d}^{-1}$ and $(6.2 \pm 0.1) \mathrm{mg}_{\mathrm{dw}} \mathrm{L}^{-1} \mathrm{~d}^{-1}$, respectively.

Table 2. Specific growth rates $\left(\mu\right.$, in $\left.\mathrm{d}^{-1}\right)$, maximum biomass concentrations $\left(X_{\max }\right.$, in $\left.\mathrm{mg}_{\mathrm{dw}} \mathrm{L}^{-1}\right)$, and maximum and average biomass productivities $\left(P_{\text {max }}\right.$ and $P_{\text {aver }}$, in $\left.\mathrm{mg}_{\mathrm{dw}} \mathrm{L}^{-1} \mathrm{~d}^{-1}\right)$ determined for $C$. vulgaris grown in raw and diluted secondary-treated paper industry effluent.

\begin{tabular}{|c|c|c|c|c|c|c|}
\hline Assay & $\begin{array}{c}\left(\mathrm{NO}_{3}+\mathrm{NO}_{2}\right)-\mathrm{N} \\
\left(\mathrm{mg}_{\mathrm{N}} \mathrm{L}^{-1}\right)\end{array}$ & $\begin{array}{c}\mathrm{PO}_{4}-\mathrm{P} \\
\left(\mathrm{mg}_{\mathrm{P}} \mathrm{L}^{-1}\right)\end{array}$ & $\underset{\left(d^{-1}\right)}{\mu}$ & $\begin{array}{c}X_{\max } \\
\left(\mathrm{mg}_{\mathrm{dw}} L^{-1}\right)\end{array}$ & $\begin{array}{c}P_{\max } \\
\left(m_{d w} L^{-1} d^{-1}\right)\end{array}$ & $\begin{array}{c}P_{\text {aver }} \\
\left(m_{d w} L^{-1} d^{-1}\right)\end{array}$ \\
\hline 1 & 34.2 & 12.7 & $0.093 \pm 0.007^{\mathrm{a}}$ & $136 \pm 1^{a}$ & $9.8 \pm 0.2^{a}$ & $6.22 \pm 0.09^{a}$ \\
\hline 2 & 28.3 & 8.55 & $0.11 \pm 0.01^{\mathrm{ab}}$ & $191 \pm 10^{\mathrm{ab}}$ & $15 \pm 2^{a b}$ & $11 \pm 1^{\mathrm{ab}}$ \\
\hline 3 & 21.5 & 6.04 & $0.136 \pm 0.004^{b c}$ & $229 \pm 16^{b}$ & $24 \pm 7^{\mathrm{ab}}$ & $15 \pm 1^{b}$ \\
\hline 4 & 16.7 & 4.22 & $0.134 \pm 0.002^{b c}$ & $249 \pm 14^{b}$ & $30 \pm 3^{b}$ & $16 \pm 1^{b}$ \\
\hline 5 & 12.7 & 4.01 & $0.16 \pm 0.02^{c}$ & $231 \pm 31^{b}$ & $30 \pm 6^{b}$ & $15 \pm 3^{b}$ \\
\hline
\end{tabular}

Values are presented as the mean \pm standard deviation obtained from two independent experiments. Within the same column, mean values sharing at least one common letter (in superscript) are not statistically different $(p>0.05)$.

In contrast to what was observed by Gentili [13], the increment in nitrogen and phosphorus concentration did not contribute to an increase in kinetic growth parameters. Accordingly, these results may indicate inhibitory effects of the effluent on microalgae, which can influence microalgal cultures in different ways [19-21]: (i) the effluent color may act as a barrier to light penetration, thus limiting microalgal access to light and photosynthetic activity; and (ii) paper industry effluents are characterized by the presence of lignin, humic acids, furans, and dioxins and by high levels of aluminum and manganese, which exhibit toxic effects on microalgae.

Most studies regarding the bioremediation of paper industry effluents with microalgae focus on the removal of contaminants and only a few report biomass production yields. Polishchuk, et al. [20] reported that the maximum specific growth rate obtained for Nannochloropsis oculata grown in effluents resulting from pulp and paper industry was $0.405 \mathrm{~d}^{-1}$. Tao, et al. [19] revealed that maximum biomass concentrations achieved by Scenedesmus acuminatus and C. vulgaris grown in paper industry effluents were $291 \mathrm{mg} \mathrm{L}^{-1}$ and $822 \mathrm{mg} \mathrm{L}^{-1}$, respectively. Considering the values referred in the literature, microalgal growth parameters obtained in this study were significantly lower, which can be attributed to the inhibitory effects promoted by the effluent used (in assays 1-3) and to the low concentration of some essential nutrients (in more diluted effluents of assays 4 and 5). Another explanation for the low biomass concentrations and productivities achieved may be related to the phenomenon of flakes formation observed within the cultivation period (autoflocculation). Cells' agglomeration can affect the accurate measurement of $\mathrm{OD}_{680}$ and, on the other hand, it can reduce light absorption efficiency by cells incorporated within flakes, thus resulting in lower photosynthetic activity. In this study, this phenomenon occurred due to the increase of culture $\mathrm{pH}$ (from 7.8 to 8.6) or due to the presence of certain compounds in the effluent, which can induce a change in the surface charge of the cells and affect suspensions' stability [22]. Despite the low microalgal growth rates, the flakes formation enables a cost-effective biomass removal after effluent remediation. The density similar to water and small size of microalgal cells difficult the harvesting process and make this step one of the most expensive within microalgal biomass production processes [22,23]. However, when cells agglomerate, an increase in 
their density and size is observed, contributing to higher settling rates and allowing biomass recovery using the least expensive harvesting method: sedimentation.

\subsection{Nutrients Removal}

In this study, nitrogen (in the forms of nitrate and nitrite) and phosphorus (in the form of phosphate) concentrations were monitored within the cultivation time to evaluate the potential of $C$. vulgaris to uptake these nutrients from a paper industry effluent with different concentrations of both nitrogen and phosphorus. Figure 3 shows the variation of nitrogen and phosphorus concentration in each assay. Regarding nitrogen removal (Figure 3A), this element was readily assimilated by C. vulgaris in the diluted effluents (assays $2-5$ ). In the raw effluent (corresponding to assay 1 ), a two-day delay was observed in nitrogen assimilation, which may be related to the adaptation of the microalga to these conditions. Regarding the assimilation patterns observed in assays $2-5$, these were approximately linear for assays $2-4$, with nitrogen concentration decreasing gradually during the cultivation time. On the other hand, in assay 5, corresponding to the more diluted effluent experiments, nitrogen concentration decreased until the seventh day of culturing and then it was maintained approximately constant. This behavior may be attributed to a decrease in photosynthetic activity, as nitrogen concentration decreased, and explains the lower biomass concentrations achieved in assay 5 when compared to the one obtained in assay 4 (according to Table 2, $(231 \pm 31) \mathrm{mg}_{\mathrm{dw}} \mathrm{L}^{-1}$ and $(249 \pm 14)$ $\mathrm{mg}_{\mathrm{dw}} \mathrm{L}^{-1}$, respectively). Also, at the end of the cultivation time, nitrogen concentration remaining in cultures corresponding to assays 4 and 5 was approximately the same $\left((2.81 \pm 0.05) \mathrm{mg}_{\mathrm{N}} \mathrm{L}^{-1}\right.$ and $(2.6 \pm 0.2) \mathrm{mg}_{\mathrm{N}} \mathrm{L}^{-1}$, respectively), indicating a limitation of this nutrient in the last days of assay 5 . As for nitrogen concentration, phosphorus concentration also decreased within the cultivation time (Figure 3B), but in a lesser extent, which is related with microalgal nutritional requirements, as given by its typical elemental biochemical composition: $\mathrm{CO}_{0.48} \mathrm{H}_{1.83} \mathrm{~N}_{0.11} \mathrm{P}_{0.01}$ [24]. The reduction observed in nitrogen and phosphorus concentration in the studied effluent (raw or diluted) shows that $C$. vulgaris can promote an efficient uptake of both nutrients. However, except for nitrogen concentration in assay 5 , total depletion of these nutrients did not occur after the 11 days of culturing, reiterating what was stated in relation to cell growth, that the cultures could be extended for an increased period to further improve nutrients removal efficiencies. Another similarity with the microalgal growth parameters already described is the higher variations in nitrogen and phosphorus concentrations observed in the experiments where the effluent was previously diluted (assays 2-5), which indicate that these conditions were more favorable for $C$. vulgaris photosynthetic activity.

Nitrogen and phosphorus removal parameters are presented in Figures 4 and 5, respectively. As with microalgal growth parameters, a general increase in nutrients removal efficiencies was observed from assay 1 to 5 , with values ranging from $(24 \pm 10) \%$ to $(80 \pm 4) \%$ for nitrogen (Figure $4 \mathrm{~A})$ and from $(13.0 \pm 0.9) \%$ to $(54 \pm 1) \%$ for phosphorus (Figure $5 \mathrm{~A})$. However, Figure $4 \mathrm{~A}$ shows that there was no statistical difference $(p>0.05)$ in nitrogen removal efficiency between assays 4 and 5 , which can be explained by the low concentration achieved in the assay 5 (the one corresponding to the most diluted effluent) that might have been limiting for microalgal growth. In fact, according to Table 2, maximum biomass concentration achieved in assay 4 was higher than that in assay 5 , indicating that the highest dilution applied in this study may have contributed to nitrogen limitation to C. vulgaris, with effects on their growth and nutrients removal parameters. Regarding nitrogen removal rates (Figure 4B) and mass removal (Figure 4C), the highest values were determined in assays 3 and 4 and no statistical differences were observed $(p>0.05)$ : (i) average removal rates were $(1.31 \pm 0.07) \mathrm{mg}_{\mathrm{N}} \mathrm{L}^{-1}$ $\mathrm{d}^{-1}$ and $(1.26 \pm 0.08) \mathrm{mg}_{\mathrm{N}} \mathrm{L}^{-1} \mathrm{~d}^{-1}$, respectively; and (ii) mass removal values were $(14.4 \pm 0.8) \mathrm{mg}_{\mathrm{N}} \mathrm{L}^{-1}$ and $(13.9 \pm 0.9) \mathrm{mg}_{\mathrm{N}} \mathrm{L}^{-1}$, respectively. These results are in accordance with maximum biomass concentration achieved and indicate higher photosynthetic activity of $C$. vulgaris in these intermediate conditions. A different behavior was observed for phosphorus. In this case, average removal rates (Figure 5B) and mass removal values (Figure 5C) determined for assays 1 to 4 were not statistically 
different $(p>0.05)$, but values determined for assay 5 were statistically higher $(p<0.05)$, reaching an average removal rate of $(0.20 \pm 0.01) \mathrm{mg}_{\mathrm{P}} \mathrm{L}^{-1} \mathrm{~d}^{-1}$ and a mass removal of $(2.2 \pm 0.1) \mathrm{mg}_{\mathrm{P}} \mathrm{L}^{-1}$.

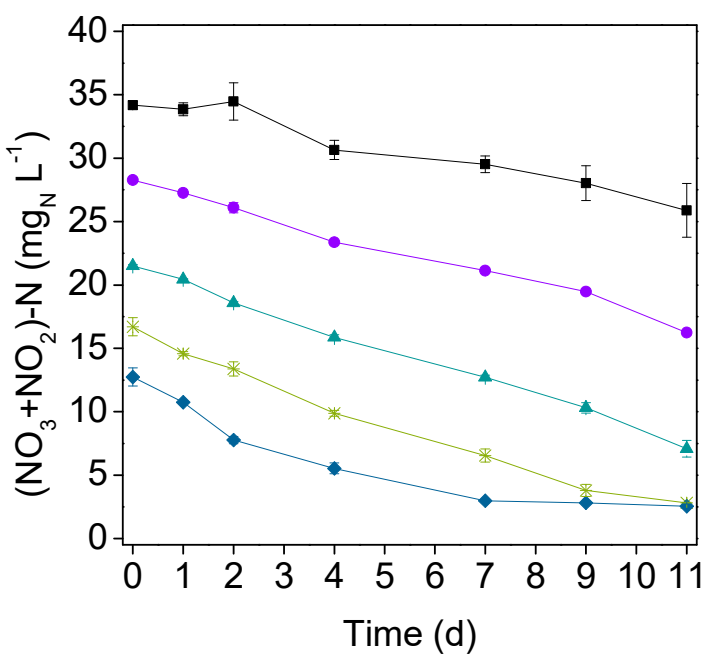

(A)

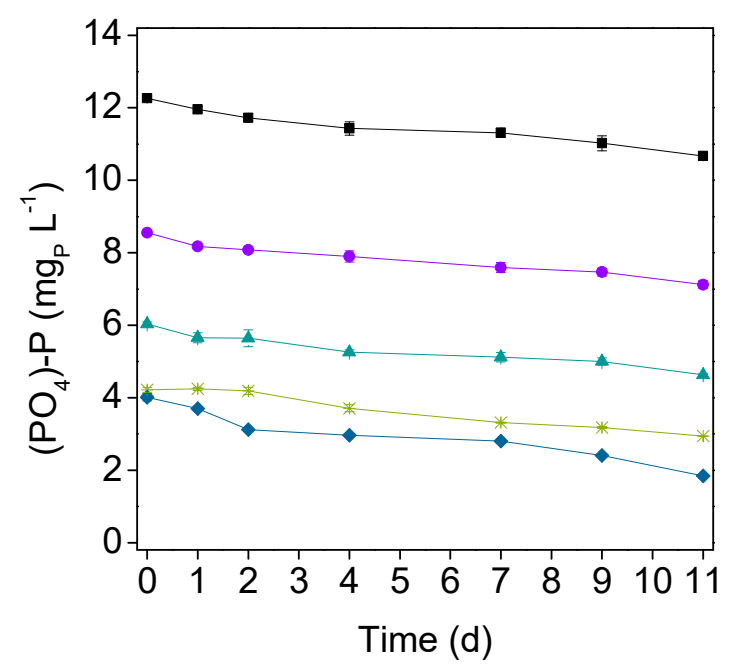

(B)

Figure 3. Temporal variation of (A) nitrogen (nitrate + nitrite) and (B) phosphorus (phosphate) concentration determined in $C$. vulgaris cultures grown in raw and diluted secondary-treated paper industry effluent (Assays: $1 \longrightarrow-2-, 3-1-, 4+$ and $5-$ ). Error bars correspond to the standard deviation of the mean obtained from two independent experiments.

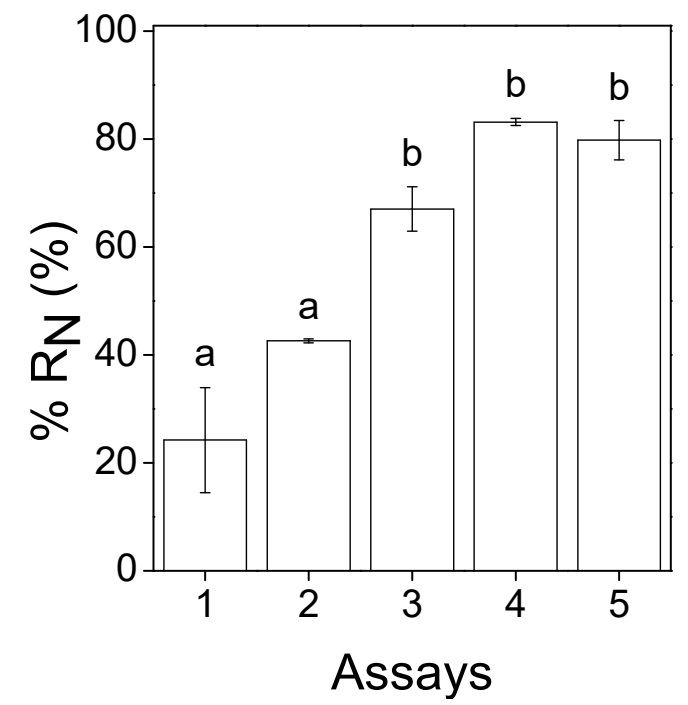

(A)

Figure 4. Cont. 


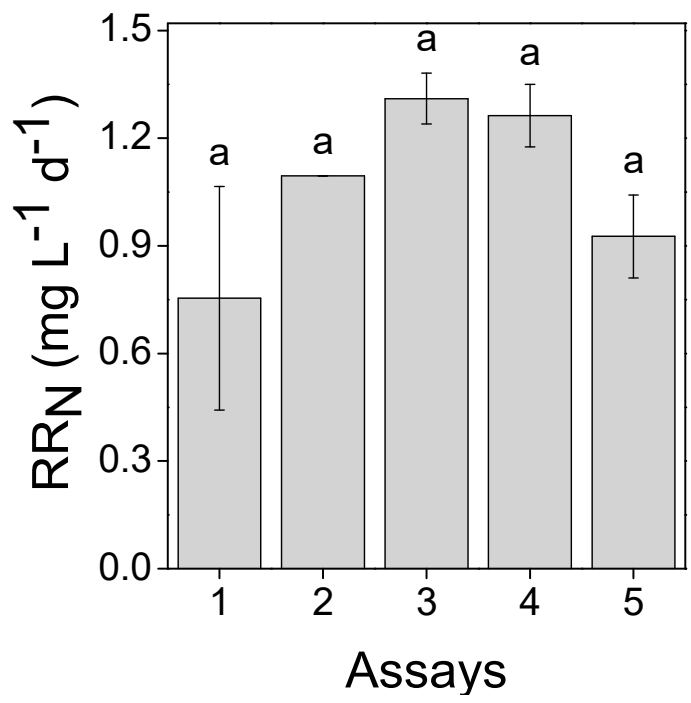

(B)

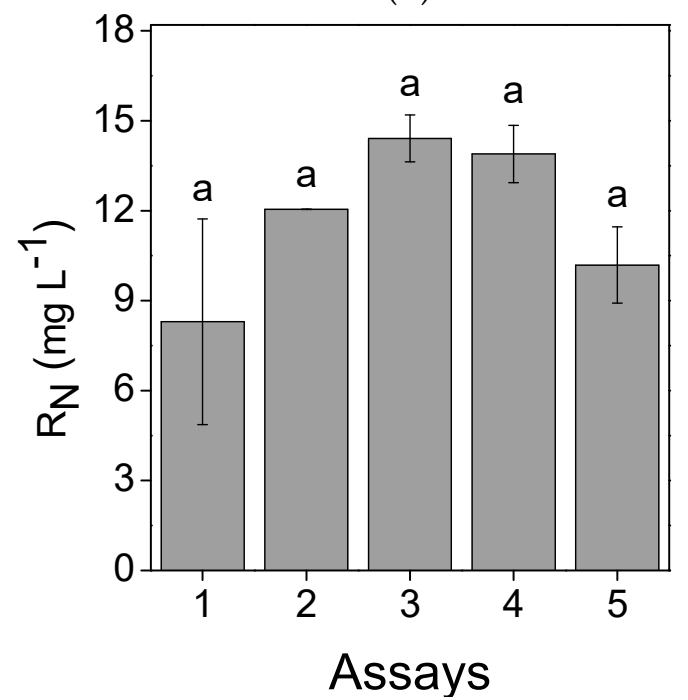

(C)

Figure 4. Nitrogen (nitrate + nitrite) removal parameters obtained by C. vulgaris cultures grown in raw and diluted secondary-treated paper industry effluent (assays 1-5): (A) removal efficiency $\left(\% \mathrm{R}_{\mathrm{N}}\right)$; (B) average removal rate $\left(R R_{N}\right)$; and $(C)$ mass removal $\left(R_{N}\right)$. Error bars correspond to the standard deviation of the mean obtained from two independent experiments. Mean values sharing at least one common letter (shown above the bars) are not statistically different $(p>0.05)$. 


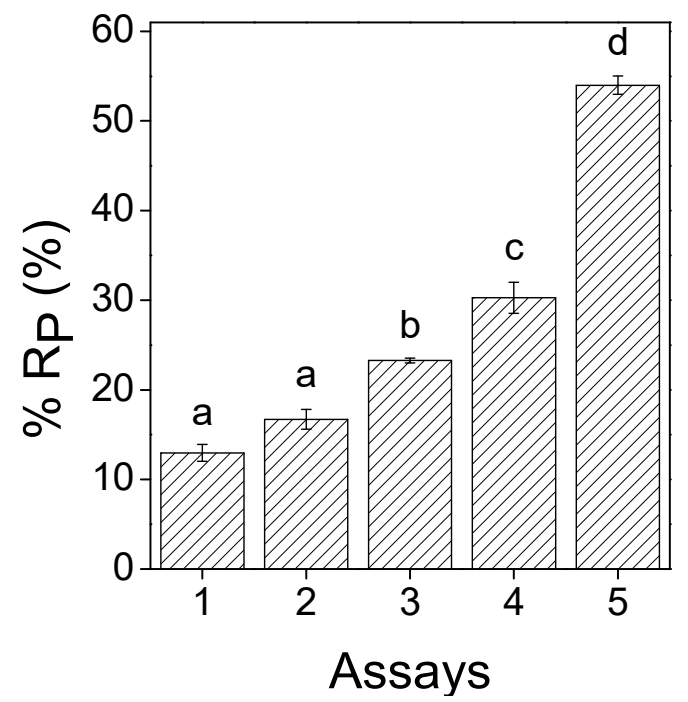

(A)

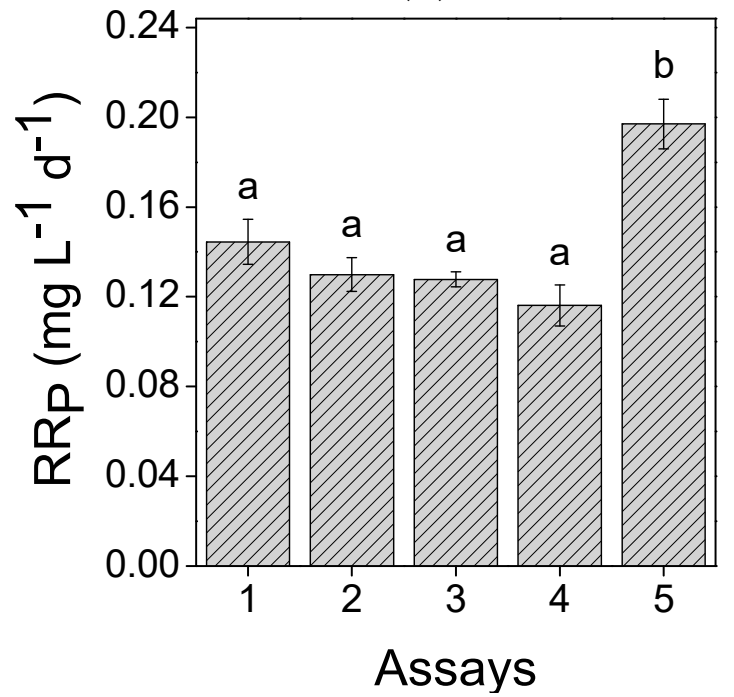

(B)

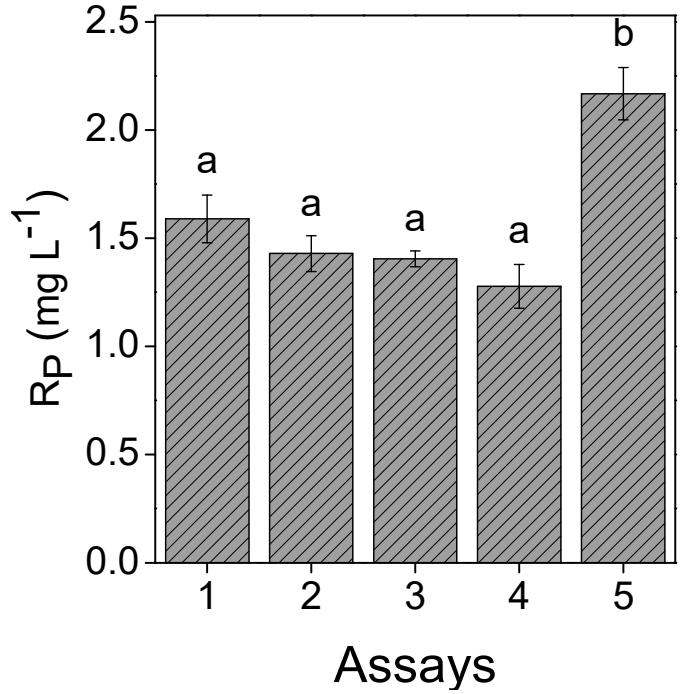

(C)

Figure 5. Phosphorus (phosphate) removal parameters obtained by C. vulgaris cultures grown in raw and diluted secondary-treated paper industry effluent (assays 1-5): (A) removal efficiency $\left(\% R_{P}\right)$; (B) average removal rate $\left(R R_{P}\right)$; and $(C)$ mass removal $\left(R_{P}\right)$. Error bars correspond to the standard deviation of the mean obtained from two independent experiments. Mean values sharing at least one common letter (shown above the bars) are not statistically different $(p>0.05)$. 
Nutrients removal from paper industry effluents has already been reported in the literature. Table 3 highlights nitrogen and phosphorus removal efficiencies and removal rates obtained in these studies. According to these data, removal efficiencies reported by Tao, et al. [19] and Gentili [2] are significantly higher than those obtained in this study, whereas values reported by Usha, et al. [1] were closer to those obtained in the present study, especially in assays 3-5. The lower removal efficiencies obtained in this study when compared with those reported by Tao, et al. [19], may be associated with the higher N:P molar ratio used in the reference study, which was $\sim 66: 1$. On the other hand, the higher removal efficiencies reported by Gentili [13] may be associated with the use of other effluents to achieve the dual role of providing the required nutrients for microalgal growth while contributing to a reduction in the toxicity of the paper industry effluent. Another explanation for the increased efficiencies obtained in these studies is the nitrogen source used. As in the present study, Usha, et al. [1] cultivated microalgae in an effluent with nitrate-nitrogen as the main nitrogen source. On the other hand, Tao, et al. [19] tested an effluent with ammonium as the main nitrogen source (digestate obtained from the treatment of a pulp and paper industry effluent) and Gentili [13] evaluated this treatment with both nitrogen forms present. According to several studies, although nitrate-nitrogen is the most thermodynamically stable form (and the most commonly found in aquatic environments), ammonia is directly assimilated and converted into proteins by microalgae, while nitrate must be reduced to nitrite and then to ammonia before being assimilated by microalgal cells [25]. However, for an adequate comparison of nutrients removal performance, it is important to determine the average removal rate, as this parameter takes into account initial nutrients concentrations and cultivation/treatment time. Comparing average removal rates obtained in the present study and in the reference studies, values in the same order of magnitude were obtained, except in what concerns ammonium-nitrogen removal in the studies performed by Tao, et al. [19] and Gentili [2]. In these cases, the higher removal rates obtained may be associated with the higher ability of microalgae to assimilate ammonium-nitrogen than nitrate-nitrogen. Considering values of average RR, it is possible to conclude that promising results were obtained in this study. Moreover, differences found in experimental conditions used in this study and in the studies reported in the literature demonstrate that these results can be significantly enhanced. Besides increasing N:P molar ratio and providing an ammonium-nitrogen source, the increase of light supply should also be considered, as values reported in the literature correspond to cultures grown under light intensities of $130-800 \mu \mathrm{mol} \mathrm{m} \mathrm{m} \mathrm{s}^{-1}$, whereas results reported in the present study were obtained with light intensities of $30-40 \mu \mathrm{mol} \mathrm{m} \mathrm{m}^{-2} \mathrm{~s}^{-1}$.

In summary, the results obtained in this study for both nitrogen and phosphorus removal evidence that the remediation of paper industry effluents using microalgae is possible, provided that it is properly diluted to avoid inhibitory effects related to the presence of strong color or high concentrations of toxic compounds, typically associated with effluents resulting from this industrial sector [19,20]. Considering the results obtained for nitrogen removal, the dilution of the effluent to the concentrations present in assays 3 and 4 is the most adequate. In these conditions, nitrogen concentrations were significantly reduced, reaching $(7.1 \pm 0.7) \mathrm{mg}_{\mathrm{N}} \mathrm{L}^{-1}$ and $(2.81 \pm 0.05) \mathrm{mg}_{\mathrm{N}} \mathrm{L}^{-1}$, respectively (which corresponds to the highest average removal rates: $(1.31 \pm 0.07) \mathrm{mg}_{\mathrm{N}} \mathrm{L}^{-1} \mathrm{~d}^{-1}$ and $(1.26 \pm 0.09) \mathrm{mg}_{\mathrm{N}} \mathrm{L}^{-1} \mathrm{~d}^{-1}$, respectively). Regarding phosphorus removal, the highest removal rate was obtained for the conditions tested in assay 5: $(0.20 \pm 0.01) \mathrm{mg}_{\mathrm{P}} \mathrm{L}^{-1} \mathrm{~d}^{-1}$. 
Table 3. Comparison between nutrients removal efficiencies ( $\% \mathrm{R}$, in $\%)$ and average removal rates ( $R R$, in $\mathrm{mg} \mathrm{L}^{-1} \mathrm{~d}^{-1}$ ) obtained in this study and other studies reporting microalgal growth in effluents resulting from pulp and paper industries.

\begin{tabular}{|c|c|c|c|c|c|c|c|}
\hline Effluent & Microalgae & $\begin{array}{l}\text { Culture Time } \\
\text { (d) }\end{array}$ & Element / Form & $\begin{array}{c}\text { Initial } \\
\text { Concentration } \\
\left(\mathrm{mg} \mathrm{L}^{-1}\right)\end{array}$ & $\begin{array}{l}\% R \\
(\%)\end{array}$ & $\begin{array}{c}\mathrm{RR} \\
\left(\mathrm{mg} \mathrm{L}^{-1}\right. \\
\left.\mathrm{d}^{-1}\right)\end{array}$ & Ref. \\
\hline \multirow{10}{*}{ Paper } & \multirow{10}{*}{ C. vulgaris } & \multirow{10}{*}{11} & $\left(\mathrm{NO}_{3}+\mathrm{NO}_{2}\right)-\mathrm{N}$ & 34.2 & 24 & 0.75 & \multirow{10}{*}{ This study } \\
\hline & & & $\mathrm{PO}_{4}-\mathrm{P}$ & 12.3 & 13 & 0.14 & \\
\hline & & & $\left(\mathrm{NO}_{3}+\mathrm{NO}_{2}\right)-\mathrm{N}$ & 28.2 & 43 & 1.1 & \\
\hline & & & $\mathrm{PO}_{4}-\mathrm{P}$ & 8.55 & 17 & 0.13 & \\
\hline & & & $\left(\mathrm{NO}_{3}+\mathrm{NO}_{2}\right)-\mathrm{N}$ & 21.5 & 67 & 1.3 & \\
\hline & & & $\mathrm{PO}_{4}-\mathrm{P}$ & 6.04 & 23 & 0.13 & \\
\hline & & & $\left(\mathrm{NO}_{3}+\mathrm{NO}_{2}\right)-\mathrm{N}$ & 16.7 & 83 & 1.3 & \\
\hline & & & $\mathrm{PO}_{4}-\mathrm{P}$ & 4.22 & 30 & 0.12 & \\
\hline & & & $\left(\mathrm{NO}_{3}+\mathrm{NO}_{2}\right)-\mathrm{N}$ & 12.7 & 80 & 0.93 & \\
\hline & & & $\mathrm{PO}_{4}-\mathrm{P}$ & 4.01 & 54 & 0.20 & \\
\hline \multirow{2}{*}{$\begin{array}{l}\text { Pulp and } \\
\text { paper mill }\end{array}$} & \multirow{2}{*}{ C. vulgaris } & \multirow{2}{*}{14} & $\mathrm{NH}_{4}-\mathrm{N}$ & 240 & 99 & 17 & \multirow{2}{*}{ [19] } \\
\hline & & & $\mathrm{PO}_{4}-\mathrm{P}$ & 8.00 & 97 & 0.55 & \\
\hline \multirow{9}{*}{$\begin{array}{c}\text { Pulp and } \\
\text { paper with } \\
\text { dairy sludge } \\
\text { and municipal }\end{array}$} & \multirow{9}{*}{$\begin{array}{l}\text { Scenedesmus sp. } \\
\text { Scenedesmus } \\
\text { dimorphus } \\
\text { Selenastrum } \\
\text { minutum }\end{array}$} & \multirow{9}{*}{6} & $\mathrm{NH}_{4}-\mathrm{N}$ & 22.4 & 99 & 3.7 & \multirow{9}{*}{ [13] } \\
\hline & & & $\mathrm{NO}_{3}-\mathrm{N}$ & 1.06 & $27-53$ & $0.048-0.094$ & \\
\hline & & & $\mathrm{PO}_{4}-\mathrm{P}$ & 10.1 & $96-98$ & $1.6-1.7$ & \\
\hline & & & $\mathrm{NH}_{4}-\mathrm{N}$ & 14.8 & $96-98$ & $2.3-2.4$ & \\
\hline & & & $\mathrm{NO}_{3}-\mathrm{N}$ & 1.08 & $41-46$ & $0.074-0.083$ & \\
\hline & & & $\mathrm{PO}_{4}-\mathrm{P}$ & 1.60 & $96-97$ & $0.25-0.26$ & \\
\hline & & & $\mathrm{NH}_{4}-\mathrm{N}$ & 21.0 & 99 & 3.5 & \\
\hline & & & $\mathrm{NO}_{3}-\mathrm{N}$ & 1.25 & $27-43$ & $0.056-0.090$ & \\
\hline & & & $\mathrm{PO}_{4}-\mathrm{P}$ & 2.99 & $90-94$ & $0.45-0.47$ & \\
\hline \multirow{2}{*}{ Paper mill } & \multirow{2}{*}{ Scenedesmus sp. } & \multirow{2}{*}{28} & $\mathrm{NO}_{3}-\mathrm{N}$ & 2.24 & 65 & 0.052 & \multirow{2}{*}{ [1] } \\
\hline & & & $\mathrm{PO}_{4}-\mathrm{P}$ & 9.86 & 71 & 0.25 & \\
\hline
\end{tabular}

Despite the promising nitrogen and phosphorus removal rates, the results obtained in this study demonstrated that the cultures were limited by nitrogen, as nitrogen and phosphorus were assimilated by C. vulgaris at a N:P molar ratio ranging from 10:1 to 24:1. Considering these results and the N:P molar ratios used in this study (between 6:1 and 9:1), nutrients uptake could be enhanced by increasing nitrogen supply. Another alternative to achieve an adequate N:P molar ratio and reduce the toxicity of this effluent would be to dilute it with other effluents, as proposed in other studies [13]. Finally, the remediation process could be further improved by modulating microalgal cultivation conditions. According to Gonçalves, et al. [25], light conditions, temperature, and $\mathrm{pH}$ are also important parameters that can influence microalgal growth and, hence, the efficiency of the bioremediation process. Thus, from the prospecting of this work, other studies evaluating these parameters should be carried out to further improve nitrogen and phosphorus uptake from paper industry effluents.

\section{Conclusions}

This study showed the feasibility of using C. vulgaris for the bioremediation of a paper industry effluent fortified with a nitrogen source, targeting phosphorus removal. C. vulgaris was able to grow in all studied effluent conditions (in non-diluted and diluted ones). However, it was possible to conclude that growing on non-diluted effluent resulted in lower biomass productivities, which was also reflected in nitrogen and phosphorus removal efficiencies. From microalgal growth and nitrogen removal points of view, the effluent dilutions used in assays 3 and 4 (intermediate dilutions) seem to be the most adequate, as microalgal growth was not inhibited in these conditions and nitrogen mass removal was quite satisfactory, achieving final concentrations of $(7.1 \pm 0.7) \mathrm{mg}_{\mathrm{N}} \mathrm{L}^{-1}$ and $(2.81 \pm 0.05) \mathrm{mg}_{\mathrm{N}} \mathrm{L}^{-1}$, respectively. Regarding phosphorus removal, concentrations achieved in the last day of culturing in assays 3 and 4 were higher $\left((4.63 \pm 0.04) \mathrm{mg}_{\mathrm{P}} \mathrm{L}^{-1}\right.$ and $(2.940 \pm 0.005) \mathrm{mg}_{\mathrm{P}} \mathrm{L}^{-1}$, respectively) than the one obtained in assay $5\left((1.85 \pm 0.02) \mathrm{mg}_{\mathrm{P}} \mathrm{L}^{-1}\right)$. However, the results obtained in assay 5 suggest a growth limitation, mainly related to nitrogen concentration. Accordingly, the obtained results indicate that these 
values can be further improved by studying different N:P molar ratios, different microalgal cultivation conditions, dilution with other effluents, among others. Improving the remediation performance can significantly contribute to the development of an effective microalgae-based remediation process of pulp and paper industry effluents.

Author Contributions: Conceptualization, B.P., A.L.G., V.J.PV. and J.C.M.P.; methodology, B.P., A.L.G. and J.C.M.P.; investigation, B.P. and A.F.E.; resources, V.J.P.V. and J.C.M.P.; data curation, B.P., A.L.G., A.F.E., V.J.P.V. and J.C.M.P.; writing (original draft preparation), B.P.; writing (review and editing), B.P., A.L.G., A.F.E., S.M.A.G.U.d.S., A.A.U.d.S., V.J.P.V. and J.C.M.P.; supervision, A.L.G., S.M.A.G.U.d.S., A.A.U.d.S., V.J.P.V. and J.C.M.P.; project administration, S.M.A.G.U.d.S., A.A.U.d.S., V.J.P.V. and J.C.M.P.; funding acquisition, S.M.A.G.U.d.S., A.A.U.d.S., V.J.P.V. and J.C.M.P. All authors have read and agreed to the published version of the manuscript.

Funding: This research was funded by: (i) Base Funding-UIDB/00511/2020 of the Laboratory for Process Engineering, Environment, Biotechnology, and Energy-LEPABE-funded by national funds through the FCT/MCTES (PIDDAC); (ii) Base Funding-UIDB/50020/2020 of the Associate Laboratory LSRE-LCM-funded by national funds through FCT/MCTES (PIDDAC); (iii) Project PTDC/BTA-BTA/31736/2017-POCI-01-0145-FEDER031736-funded by FEDER funds through COMPETE2020-Programa Operacional Competitividade e Internacionalização (POCI) and with financial support of FCT/MCTES through national funds (PIDDAC); and (iv) the Coordenação de Aperfeiçoamento de Pessoal de Nível Superior_Brasil (CAPES)_Finance Code 001. V.J.P. Vilar acknowledges the FCT Individual Call to Scientific Employment Stimulus 2017 (CEECIND/01317/2017). J.C.M. Pires acknowledges the FCT Investigator 2015 Programme (IF/01341/2015).

Conflicts of Interest: The authors declare no conflict of interest.

\section{References}

1. Usha, M.T.; Sarat Chandra, T.; Sarada, R.; Chauhan, V.S. Removal of nutrients and organic pollution load from pulp and paper mill effluent by microalgae in outdoor open pond. Bioresour. Technol. 2016, 214, 856-860. [CrossRef] [PubMed]

2. Reid, N.; Bowers, T.; Lloyd-Jones, G. Bacterial community composition of a wastewater treatment system reliant on $\mathrm{N}_{2}$ fixation. Appl. Microbiol. Biotechnol. 2008, 79, 285-292. [CrossRef]

3. Pokhrel, D.; Viraraghavan, T. Treatment of pulp and paper mill wastewater-A review. Sci. Total Environ. 2004, 333, 37-58. [CrossRef] [PubMed]

4. Piao, W.; Kim, Y.; Kim, H.; Kim, M.; Kim, C. Life cycle assessment and economic efficiency analysis of integrated management of wastewater treatment plants. J. Clean. Prod. 2016, 113, 325-337. [CrossRef]

5. Singh, G.; Thomas, P.B. Nutrient removal from membrane bioreactor permeate using microalgae and in a microalgae membrane photoreactor. Bioresour. Technol. 2012, 117, 80-85. [CrossRef]

6. Zang, Y.; Li, Y.; Wang, C.; Zhang, W.; Xiong, W. Towards more accurate life cycle assessment of biological wastewater treatment plants: A review. J. Clean. Prod. 2015, 107, 676-692. [CrossRef]

7. Tarlan, E.; Dilek, F.B.; Yetis, U. Effectiveness of algae in the treatment of a wood-based pulp and paper industry wastewater. Bioresour. Technol. 2002, 84, 1-5. [CrossRef]

8. Li, K.; Liu, Q.; Fang, F.; Luo, R.; Lu, Q.; Zhou, W.; Huo, S.; Cheng, P.; Liu, J.; Addy, M.; et al. Microalgae-based wastewater treatment for nutrients recovery: A review. Bioresour. Technol. 2019, 291, 121934. [CrossRef]

9. Pires, J.C.M.; Alvim-Ferraz, M.C.M.; Martins, F.G.; Simões, M. Carbon dioxide capture from flue gases using microalgae: Engineering aspects and biorefinery concept. Renew. Sustain. Energy Rev. 2012, 16, 3043-3053. [CrossRef]

10. Rawat, I.; Kumar, R.R.; Mutanda, T.; Bux, F. Dual role of microalgae: Phycoremediation of domestic wastewater and biomass production for sustainable biofuels production. Appl. Energy 2011, 88, 3411-3424. [CrossRef]

11. Odjadjare, E.C.; Mutanda, T.; Olaniran, A.O. Potential biotechnological application of microalgae: A critical review. Crit. Rev. Biotechnol. 2017, 37,37-52. [CrossRef] [PubMed]

12. Rizwan, M.; Mujtaba, G.; Memon, S.A.; Lee, K.; Rashid, N. Exploring the potential of microalgae for new biotechnology applications and beyond: A review. Renew. Sustain. Energy Rev. 2018, 92, 394-404. [CrossRef]

13. Gentili, F.G. Microalgal biomass and lipid production in mixed municipal, dairy, pulp and paper wastewater together with added flue gases. Bioresour. Technol. 2014, 169, 27-32. [CrossRef] [PubMed]

14. OECD. Test. No. 201: Freshwater Alga and Cyanobacteria. In Growth Inhibition Test; Organization for Economic Co-operation and Development: Paris, France, 2011. [CrossRef] 
15. Rice, E.W.; Bridgewater, L.; Association, A.P.H.; Association, A.W.W.; Federation, W.E. Standard Methods for the Examination of Water and Wastewater, 22nd ed.; American Public Health Association: Washington, DC, USA, 2012; p. 724.

16. Silva, N.F.P.; Gonçalves, A.L.; Moreira, F.C.; Silva, T.F.C.V.; Martins, F.G.; Alvim-Ferraz, M.C.M.; Boaventura, R.A.R.; Vilar, V.J.P.; Pires, J.C.M. Towards sustainable microalgal biomass production by phycoremediation of a synthetic wastewater: A kinetic study. Algal Res. 2015, 11, 350-358. [CrossRef]

17. Larsdotter, K. Wastewater treatment with microalgae-A literature review. Vatten 2006, 62, 31.

18. Hodaifa, G.; Martínez, M.E.; Sánchez, S. Use of industrial wastewater from olive-oil extraction for biomass production of Scenedesmus obliquus. Bioresour. Technol. 2008, 99, 1111-1117. [CrossRef]

19. Tao, R.; Kinnunen, V.; Praveenkumar, R.; Lakaniemi, A.-M.; Rintala, J.A. Comparison of Scenedesmus acuminatus and Chlorella vulgaris cultivation in liquid digestates from anaerobic digestion of pulp and paper industry and municipal wastewater treatment sludge. J. Appl. Phycol. 2017, 29, 2845-2856. [CrossRef]

20. Polishchuk, A.; Valev, D.; Tarvainen, M.; Mishra, S.; Kinnunen, V.; Antal, T.; Yang, B.; Rintala, J.; Tyystjärvi, E. Cultivation of Nannochloropsis for eicosapentaenoic acid production in wastewaters of pulp and paper industry. Bioresour. Technol. 2015, 193, 469-476. [CrossRef]

21. Molinuevo-Salces, B.; Riaño, B.; Hernández, D.; Cruz García-González, M. Microalgae and Wastewater Treatment: Advantages and Disadvantages. In Microalgae Biotechnology for Development of Biofuel and Wastewater Treatment; Alam, M.A., Wang, Z., Eds.; Springer Singapore: Singapore, 2019; pp. 505-533.

22. Barros, A.I.; Gonçalves, A.L.; Simões, M.; Pires, J.C.M. Harvesting techniques applied to microalgae: A review. Renew. Sustain. Energy Rev. 2015, 41, 1489-1500. [CrossRef]

23. Gerde, J.A.; Yao, L.; Lio, J.; Wen, Z.; Wang, T. Microalgae flocculation: Impact of flocculant type, algae species and cell concentration. Algal Res. 2014, 3, 30-35. [CrossRef]

24. Chisti, Y. Biodiesel from microalgae. Biotechnol. Adv. 2007, 25, 294-306. [CrossRef] [PubMed]

25. Gonçalves, A.L.; Pires, J.C.M.; Simões, M. A review on the use of microalgal consortia for wastewater treatment. Algal Res. 2017, 24, 403-415. [CrossRef]

(C) 2020 by the authors. Licensee MDPI, Basel, Switzerland. This article is an open access article distributed under the terms and conditions of the Creative Commons Attribution (CC BY) license (http://creativecommons.org/licenses/by/4.0/). 